\title{
Apoptosis-induced effects of extract from Artemisia annua Linné by modulating PTEN/p53/PDK1/Akt/ signal pathways through PTEN/p53-independent manner in HCT116 colon cancer cells
}

\author{
Eun Ji Kim, Guen Tae Kim, Bo Min Kim', Eun Gyeong Lim', Sang-Yong Kim² and Young Min Kim*
}

\begin{abstract}
Background: The extracts from Artemisia annua Linné (AAE) has been known to possess various functions including anti-bacterial, anti-virus and anti-oxidant effects. However, the mechanism of those effects of AAE is not well known. Pursuantly, we determined the apoptotic effects of extract of AAE in HCT116 cell. In this study, we suggested that AAE may exert cancer cell apoptosis through PTEN/PDK1/Akt/p53signal pathway and mitochondria-mediated apoptotic proteins.

Methods: We measured 3-(4,5-dimethylthiazol-2-yl)-2,5-diphenyltetrazolium bromide (MTT) assay, lactate dehydrogenase $(\mathrm{LDH})$ assay, Hoechst 33342 staining, Annexin V-PI staining, Mitopotential assay, immunofluorescence (IF) and Western blotting. Accordingly, our study showed that AAE treatment to HCT116 cells resulted in inhibition of PDK1, Akt, MDM2, BCl-2, and pro-caspase 3 as well as activation of PTEN, p53-upregulated modulator of apoptosis (PUMA), Bax and Bak expression. Also we measured in vivo assay that xenograft model, H\&E assay, TUNEL assay and IHC.

Results: AAE induced apoptosis via PTEN/p53/PDK1/Akt signal pathways through PTEN/p53-independent manner. AAE inhibit cell viability and increase LDH release in HCT116 colon cancer cell. Also, AAE increase apoptotic bodies, caspase $-3,7$ activation and reduces mitochondria membrane potential. AAE regulates cytochrome $\mathrm{c}$ translocation to the cytoplasm and Bax translocation to the mitochondrial membrane in an Immunofluorescence staining and increase PTEN and p53 expression in an in vivo tumor xenograft model. To elucidate the role of the PTEN/p53/PDK1/Akt signal pathways in cancer control, we conditionally inactivated PTEN/p53/PDK1/Akt signal pathways. We used inhibitors of PTEN, p53, PDK1, Akt. In consequence, these results indicate that AAE induced apoptosis by means of a mitochondrial event through the regulation of proteins such as Bax, Bak and cytochrome $c$ in PDK1/Akt signaling pathways via PTEM/p53-independent manner.
\end{abstract}

Conclusions: We confirmed the apoptotic effect of extracts of AAE by Modulating PTEN/p53/PDK1/Akt/Signal Pathways through PTEN/p53-independent pathwaysin HCT116 colon cancer cell.

Keywords: Phosphatase and tensin homolog (PTEN), p53-independent manner, Artemisia annua Linné, Apoptosis, HCT116 colon cancer cell

\footnotetext{
* Correspondence: kym@hnu.kr

${ }^{1}$ Department of Biological Science and Biotechnology, College of Life

Science and Nano Technology, Hannam University, 1646 Yuseong-daero,

Yuseong-gu, Daejeon 34054, Korea

Full list of author information is available at the end of the article
} 


\section{Background}

Artemisia annua Linné is an annual plant that is chrysanthemum family. This plant is primarily found in the tropical zones of Asia along streets and in fields. Since ancient times, Artemisia annua Linné has been used as an antipyretic, hemostatic, as a treatment for skin diseases, and an insecticide. In addition, its antibacterial, antiviral and antioxidant properties allow it has been used as a traditional herbalmedicine [1]. This plant also contains various bioactive compounds [2-5].

The antioxidant activity of phenolic compounds in Artemisia annua Linné has been reported [6]. Artemisinin, the main element of sweet wormwood, is being used for medical uses, such as anti-malarial activity [7-9]. In previous studies, they determined that when using Artemisia annua Linné on extracts from breast cancer, cervical carcinoma cells, stomach cancer, and for cell growth inhibitory effect that there is a cancer cell $[10,11]$. Furthermore, selective necrosis of breast cancer cells was proven to be anti-cancer active. This brought attention to the world to consider taking action with herbal remedies [12]. Some studies have reported the effect of Artemisia annua Linné added to food and feed. However, the mechanism of the effects of Artemisia annua Linné is not well known [13].

PTEN (Phosphatase and TENsin homolog deleted on chromosome ten), a tumor-suppressorgene with dual lipid and protein phosphatase activity, antagonizes the PI3K/ AKT signaling pathway and suppresses cell survival, as well as cell proliferation. Also, PTEN can inhibit the activation of Akt. This effect has been attributed to PTEN reducing the availability of Phosphatidylinositol $(3,4,5)$ trisphosphate (PIP3; 2-3) [14-16]. The serine/threonine kinase Akt is phosphorylated and activated by PDK1 (phosphoinositide-dependent protein kinase-1) [17].

PDK1 activation phosphorylates Akt at thr308. Once phosphorylated in T308, phosphorylation additionally occurs at S473by PDK2 [18]. Akt activation induces different cell survival mechanisms [19]. Akt plays a central role in many cellular processes that establish survival factor and exert anti-apoptotic activation. Also, Akt activation induces cell cycle progression [20]. In another case, Akt prevented apoptosis via phosphorylation and translocation of MDM2 (Murine double minute 2) into the nucleus $[21,22]$. MDM2 interacts with p53 and inhibits it. Under normal circumstances, p53 is maintained at very low levels by ubiquitination and degradation [23]. The p53 gene, a tumor suppressor, plays a key role in the induction of apoptosis and cell cycle arrest in response to a variety of stress genes, including the blocker of cellular DNA damage repair [24]. p53 is a nuclear DNA-binding phosphor-protein. It is a transcriptional activator that can exert transcriptional repression of specific targeted genes [25]. Also, p53 interacts directly with cell proliferation-mediated proteins. The direct interaction of p53 activates apoptotic proteins into mitochondrial outer membrane permeabilization (MOMP) [26].

Mitochondria are well known for playing a key role in activating apoptosis. The mitochondrial apoptosis pathway is mediated via Bcl-2 family proteins [27, 28]. Bcl-2 family proteins are divided into anti-apoptotic proteins such as Bcl-XL, Bcl-w, Mcl-1 and pro-apoptotic proteins such as Bax, Bak and Bok. In normal cells, Bax exists as a monomer in the cytosol and translocates to mitochondria, experiencing conformational changes to form oligomers during apoptosis. On the other hand, Bak resides on mitochondria. During apoptosis, Bak changes to form oligomers identical to Bax. The activation of Bax and Bak regulates cytochrome c release to cytosol from the mitochondria via alteration of MOMP $[29,30]$. Released cytochrome $\mathrm{c}$ induces apoptosis by activating last effectors caspase (caspase-3/-7) [31].

In this study, we investigated the effects of Artemisia annua Linné extract (AAE) on apoptosis in HCT116colon cancer cells. We suggested that AAE induced apoptosis through PTEN/PDK1/Akt/p53signal pathways and mitochondria-mediated apoptotic proteins.

\section{Methods}

\section{Reagents and chemicals}

AAE was purchased from Daejeon Oriental Herbal Market (Deojun, Korea).3-(4,5-Dimethylthiazol-2-yl)-2,5Diphenyltetrazolium Bromide (MTT) was purchased from Sigma-Aldrich (St. Louis, MO, USA). The Pierce lactate dehydrogenase (LDH) Cytotoxicity Assay kit was purchased from Thermo Fisher Scientific (Waltham, MA, USA). The Muse Annexin V and Dead Cell Assay Kit, The Muse Caspase-3/7 Kit and the Muse MitoPotential Kit were purchased from Millipore (Darmstadt, Germany). MitoTracker was purchased from Molecular Probes (Eugene, OR, USA). Specific antibodies that recognized phosphorylated (p)Akt (Ser473) (4060S), (p)Akt (Tre308) (3038S), (p)PTEN (9549P), (p)PDK1 (3430P), PUMA (4976P) Bax (5023P), Bak (6947), pro-caspase3 (9665), Bcl-2 (2876) and $\beta$-actin (4967) total formed (t)Akt (4060P), (t)PDK1 (3062P) were obtained from Cell Signaling Technology (Beverly, MA, USA). The total formed (t)PTEN (SC-7974) was purchased from Santa Cruz Biotechnology (Dallas, TX, USA), (t)MDM2 (NBPI-02158SS) was purchased from Novus Biologicals (Littleton, CO, USA) and (p)MDM2 was purchased from Abcam (Cambridge, MA, USA). LY294002 (PI3K/Akt inhibitor), Pifithrin- $\alpha$ (p53 inhibitor) were purchased from Calbiochem (San Diego, CA, USA), Nutlin-3 (MDM2 inhibitor) and BX-795 (PDK1 inhibitor) were purchased from Sigma-Aldrich (St Louis, MO, USA), BpV (PTEN inhibitor) was purchased from Santa Cruz Biotechnology 
(Dallas, TX, USA). Horseradish peroxidase (HRP)-conjugated Goat Anti-Mouse (PA1-30126) and Goat Anti-Rabbit (166-2408) secondary antibodies were purchased from Thermo Fisher Scientific, Inc., and BioRad Laboratories, Inc., (Tokyo, Japan), respectively.

\section{Preparation of Artemisia annua Linné extract}

$100 \mathrm{~g}$ of the powdered AAE was extracted with $800 \mathrm{~mL}$ of $95 \%$ EthOH for $72 \mathrm{~h}$. The extract was filtered through qualitative filter paper no. 1 (Toyo Roshi Kaisha, Ltd.; Tokyo, Japan) and concentrated with a rotary evaporator to remove the ethanol. AAE was dissolved in dimethyl sulfoxide (DMSO) prior to treatment and stored at $-20{ }^{\circ} \mathrm{C}$. The final concentration of AAE in the culture medium was controlled at $30-60 \mu \mathrm{g} / \mathrm{ml}$.

\section{Cell culture}

HCT116 cells were obtained from the American Type Culture Collection (ATCC; Rockville, MD, USA). The cells were grown in RPMI-1640 medium (Hyclone Laboratories Inc.)containing $10 \%$ fetal bovine serum (FBS) and $1 \%$ antibiotics at $37{ }^{\circ} \mathrm{C}$ in a $5 \% \mathrm{CO}_{2}$ incubator. The cells were sub-cultured by detachment with TrypsinEDTA (Hyclone Laboratories Inc.)and re-seeded at $1 \times 10^{6}$ cells $/ \mathrm{mL}$ per $100 \mathrm{~mm}$ plate every $48 \mathrm{~h}$.

\section{3-(4,5-Dimethylthiazol-2-yl)-2,5-diphenyltetrazolium bromide (MTT) assay}

HCT116 cells and fibroblast cells $\left(1 \times 10^{5}\right)$ were seeded onto 12-well plates and treated with AAE at concentrations of 30,40 , and $60 \mu \mathrm{g} / \mathrm{mL}$ for $24 \mathrm{~h}$. Certain samples were pre-treated with a respective inhibitor $(20 \mu \mathrm{MLY} 294002,20 \mu \mathrm{M}$ Nutlin, $20 \mu \mathrm{M}$ pifithrin- $\alpha$, $1 \mu \mathrm{M} \mathrm{BpV}$ and $5 \mu \mathrm{MBX}-)$ for $30 \mathrm{~min}$ prior to treatment with AAE. The selective medium removed and then incubated with20 $\mu \mathrm{l}$ of MTT solution $(5 \mathrm{mg} / \mathrm{ml} \mathrm{MTT} \mathrm{in}$ PBS) for $1 \mathrm{~h}$. Converted purple formazan dye from MTT was solubilized in DMSO and optical densities were measured at $595 \mathrm{~nm}$.

\section{Lactate dehydrogenase (LDH)assay}

Cells were seeded at $2.5 \times 10^{5}$ cells $/ \mathrm{mL}$ per well in a 96well plate and incubated for $24 \mathrm{~h}$. The cells were then treated with $\operatorname{AAE}(30,40$, and $60 \mu \mathrm{g} / \mathrm{mL})$ and incubated at $37{ }^{\circ} \mathrm{C}$ in a $5 \% \mathrm{CO}_{2}$ atmosphere. After $24 \mathrm{~h}$, the high control cells (maximum LDH release) were treated with cell lysis solution from the LDH Cytotoxicity Assay Kit for $30 \mathrm{~min}$. The absorbance of the solution in each well was determined using a microplate reader (Bio-Rad Laboratories, Inc.) at 490 and $655 \mathrm{~nm}$.

\section{Cells morphology}

Cells were seeded at $1 \times 10^{5}$ cells $/ \mathrm{mL}$ in 6 wellplatesandtreatedwithAAEfora $24 \mathrm{~h}$ time period at 30, 40, and $60 \mu \mathrm{g} / \mathrm{ml}$ concentrations.

\section{Hoechst 33342 staining}

Cells were seeded at $1 \times 10^{4}$ cells $/ \mathrm{mL}$ in a 12 -well plate with cover glasses and incubated for $24 \mathrm{~h}$. Following incubation, the cells were treated with the $\operatorname{AAE}(30,40$, and $60 \mu \mathrm{g} / \mathrm{mL}$ ) for $24 \mathrm{~h}$ at $37{ }^{\circ} \mathrm{C}$ in a $5 \% \mathrm{CO}_{2}$ atmosphere. Cells were stained with Hoechst 33342 for 30 min. Slides were washed with PBS and mounting fluid was poured over them. The slides were covered with a cover slip and sealed with nail polish. Fluorescence was measured by using a fluorescence microscope (Carl Zeiss, Germany).

\section{Cell apoptosis assay}

HCT116 cell apoptosis was assayed using the Muse ${ }^{\mathrm{mm}}$ Annexin V and Dead Cell Kit (Merck Millipore, Guyancourt, France) according to the user's guide. A total of $1 \times 10^{5}$ cells were collected by centrifugation $(3000 \mathrm{rpm}$, $5 \mathrm{~min}$ ) and washed with PBS. Cells were resuspended in a RPMI-medium with $1 \%$ bovine serum albumin and $10 \%$ FBS, mixed with the Muse ${ }^{\mathrm{mm}}$ Annexin V and Dead Cell reagent, and then incubated for $20 \mathrm{~min}$ at room temperature in the dark. Assay results were measured using the Muse ${ }^{\text {mi }}$ Cell Analyzer.

\section{Caspase- $3 / 7$ activity analysis}

Cells were seeded at $1 \times 10^{5}$ cells $/ \mathrm{mL}$ per plate in a 6well plate and incubated for $24 \mathrm{~h}$. Following incubation, the cells were treated with $\operatorname{AAE}(30,40$, and $60 \mu \mathrm{g} / \mathrm{mL})$ for $24 \mathrm{~h}$ at $37{ }^{\circ} \mathrm{C}$ in a $5 \% \mathrm{CO}_{2}$ atmosphere. HCT116 cell caspase activity was assayed using the Muse Caspase 3/7 Assay Kit according to the user's guide. A total of $1 \mathrm{x}$ $10^{5}$ cells were collected by centrifugation $(3000 \mathrm{rpm}$, $5 \mathrm{~min}$ ) and washed with PBS. Cells were resuspended in a $1 \mathrm{X}$ Assay Buffer BA, mixed with the Muse ${ }^{\mathrm{Tu}}$ Caspase$3 / 7$ reagent, and then incubated for $20 \mathrm{~min}$ at $37^{\circ} \mathrm{C}$ in a $5 \% \mathrm{CO}_{2}$ atmosphere in the dark. After incubation, $150 \mu \mathrm{L}$ of Muse $^{\mathrm{m}}$ Caspase 7-AAD working solution was added to each tube. The solution was mixed thoroughly by pipetting up and down, also know as vortexing, at a medium speed for 3 to $5 \mathrm{~s}$. It was then incubated at room temperature for $5 \mathrm{~min}$ in the dark. Assay results were measured using the Muse ${ }^{\text {Tx }}$ Cell Analyzer.

\section{Western blotting}

Cells were seeded at $1 \times 10^{5}$ cells $/ \mathrm{mL}$ per plate in a 6 well plate and incubated for $24 \mathrm{~h}$. The cells were then treated with $\operatorname{AAE}(30,40$, and $60 \mu \mathrm{g} / \mathrm{mL})$ and incubated at $37{ }^{\circ} \mathrm{C}$ in a $5 \% \mathrm{CO}_{2}$ atmosphere. Certain samples were pre-treated with the respective inhibitor (20 $\mu$ MLY294002, 
$20 \mu \mathrm{M}$ Nutlin, $20 \mu \mathrm{M}$ pifithrin- $\alpha, 1 \mu \mathrm{M}$ Bp $\mathrm{V}$ and 5 $\mu \mathrm{MBX}-795)$ for $30 \mathrm{~min}$ prior to treatment with AAE. Cells were rinsed twice with ice cold PBS and scraped with a lysis buffer $(50 \mathrm{mM}$ Tris- $\mathrm{HCl} \mathrm{pH} 8.0,150 \mathrm{mMNaCl}, 1 \%$ NP40, 0.5\% sodium deoxycholate, $1 \mathrm{mM}$ PMSF) and subjected to western blot analysis. The primary antibody was allowed to react overnight at $4{ }^{\circ} \mathrm{C}$ and the second antibody reacted for $90 \mathrm{~min}$ at room temperature with gentle agitation. Following washing the samples four times with $1 \mathrm{X}$ Tris Buffered Saline with Tween 20 (TBST) for $10 \mathrm{~min}$ at room temperature, proteins were detected using Super Signal West Pico Chemiluminescent Substrate (PI34080; Thermo Fisher Scientific, Inc., Waltham, MA, USA) and visualized on CP-BU new X-ray film (Agfa HealthCare, Inc., Mortsel, Belgium).

\section{Mitochondrial membrane potential assay}

Cells were seeded at $1 \times 10^{5}$ cells $/ \mathrm{mL}$ per plate in a 6well plate and incubated for $24 \mathrm{~h}$. Following incubation, the cells were treated with the $\operatorname{AAE}(30,40$, and $60 \mu \mathrm{g} / \mathrm{mL})$ for $24 \mathrm{~h}$ at $37{ }^{\circ} \mathrm{C}$ in a $5 \% \mathrm{CO}_{2}$ atmosphere. HCT116 cell caspase activity was assayed using the Muse MitoPotential Kit according to the user's guide. A total of $1 \times 10^{5}$ cells were collected by centrifugation (3000 rpm, $5 \mathrm{~min}$ ) and washed with PBS. The supernatant was then removed and the cell pellets were stained with the Muse MitoPotential
Kit (Merck Millipore, Guyancourt, France) for $25 \mathrm{~min}$ at $37{ }^{\circ} \mathrm{C}$.The data was analyzed using the $\mathrm{Muse}^{\mathrm{Tm}}$ Cell Analyzer Assay.

\section{Fraction of mitochondria and cytosol proteins}

We used a Mitochondria/Cytosol Fraction Kit (Abcam, Cambridge, MA, USA). Cells were seeded at $1 \times 10^{6} / \mathrm{ml}$ on a $100 \mathrm{~mm}$ plate and incubated for $24 \mathrm{~h}$. After incubation, cells were treated with AAE for $24 \mathrm{~h}$ at $37^{\circ} \mathrm{C}$ in a $5 \% \mathrm{CO}_{2}$ atmosphere. Cells were harvested by trypsinization, collected by centrifugation, washed with PBS, and homogenized in an ice cold cytosol extraction buffer mix containing DTT and protease inhibitor using a sonicator. The homogenates were centrifuged at $3000 \mathrm{rpm}$ for $10 \mathrm{~min}$ at $4{ }^{\circ} \mathrm{C}$ and the supernatants were collected. The supernatants were centrifuged at $13000 \mathrm{rpm}$ for 30 min at $4{ }^{\circ} \mathrm{C}$ and collected. The supernatant cytosol proteins and pellets were resuspended with ice cold mitochondria extraction buffer containing DTT and a protease inhibitor for mitochondria proteins.

\section{Immunofluorescence (IF)staining}

Cells were seeded at $1 \times 10^{4}$ cells $/ \mathrm{mL}$ in a 12 -well plate with cover glasses and incubated for $24 \mathrm{~h}$. The cells were treated with the $\operatorname{AAE}(30,40$, and $60 \mu \mathrm{g} / \mathrm{mL})$ for $24 \mathrm{~h}$ at $37{ }^{\circ} \mathrm{C}$ in a $5 \% \mathrm{CO}_{2}$ atmosphere. The cells were stained
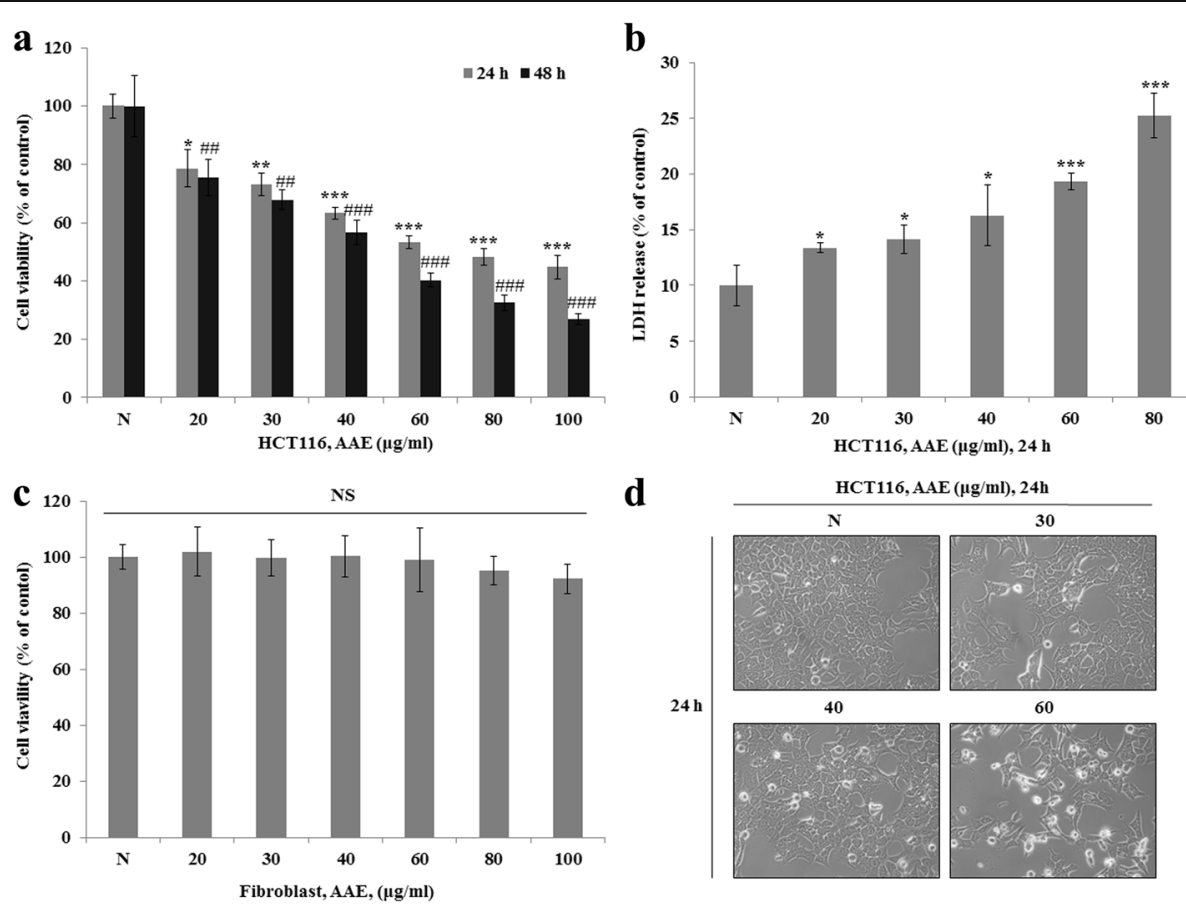

d

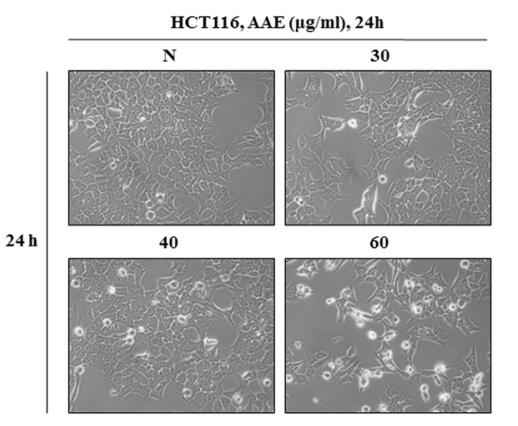

Fig. 1 AAE reduces cell proliferation in HCT116 colon cancer cells. a, c Cell viability was measured by MTT assay. $\mathbf{a}$ is HCT116 cell line. $\mathbf{c}$ is Fibroblast cell line. The statistical analysis of the data was carried out by use of an T-test. * $/ \# p<0.05,{ }^{* *} / \# \#^{\prime} p<0.01$ and ${ }^{* * *} / \# \# p<0.001$ (each experiment, $n=3$ ). b LDH assay was performed for assessing cell deaths. Cytotoxicity was induced by AAE. The statistical analysis of the data was carried out by use of an T-test. ${ }^{*} p<0.05,{ }^{* *} p<0.01$ and ${ }^{* * *} p<0.001$ (each experiment, $n=3$ ). d AAE affects the morphology of HCT116 cells, and promotes cell death in a dose-dependent manner. $\mathrm{HCT116}$ were treated with $\operatorname{AAE}(0,30,40$, and $60 \mathrm{ig} / \mathrm{ml})$ for $24 \mathrm{~h}$ 
with MitoTracker. for $30 \mathrm{~min}$ at $37{ }^{\circ} \mathrm{C}$ in a $5 \% \mathrm{CO}_{2}$ atmosphere. Cells were fixed with $3.7 \%$ formaldehyde for $20 \mathrm{~min}$ and permeabilized with $0.2 \%$ Triton X-100 for $20 \mathrm{~min}$. Cells were washed with PBS twice and reacted with cytochrome c, Bax and Bak antibodies overnight at $4{ }^{\circ} \mathrm{C}$. Cells were washed with PBS twice and reacted with a secondary antibody for $1 \mathrm{~h} 30 \mathrm{~min}$. Fluorescence was detected by confocal microscopy (Olympus; Tokyo, Japan).

\section{Xenograft model}

Five-week-old male Balb/c nudemice were obtained from SLC (SLC; Tokyo, Japan) Five mice made up the control group while five other mice made up the experimental and delivery groups for each concentration. For tumor induction, HCT116 human colon cancer cells $(2.5 \times 105$ cells $/ 0.1 \mathrm{ml})$ were subcutaneously injected into the left flank of the mice (each group had 10 animals). One week after the injection of cells, the mice were co-treated with AAE20, $40 \mathrm{mg} / \mathrm{kg} /$ day and $0.2 \mathrm{~cm}^{3}$ PBS/DMSO for 21 days. Tumor size was measured by taking two perpendicular diameter measurements, using a caliper, every 2 days. The tumor volume was calculated using the following formula: $\mathrm{V}=1 / 2$ (length $\mathrm{x}$ width). The body weight of each animal was measured at a set time, once per week. After the 3-week treatment, the tumor was removed and frozen in liquid nitrogen for western blot analysis or fixed with formalin for immunohistochemistry, TUNEL and H\&E staining. All of the animal experiments were approved by the Ethics Committee for Animal Experimentation of Hannam University (Daejeon, Korea, HNU 2016-9).

\section{TUNEL assay}

Levels of apoptosis in distal colon tissue were determined using the TdT-mediated dUTP nickend labeling (TUNEL)method. Tumor specimens from mice were fixed in $10 \%$ formaldehyde, embedded in paraffin and sectioned into $5 \mu \mathrm{m}$ thick slices. Tissue sections were processed according to manufacturer's instructions for

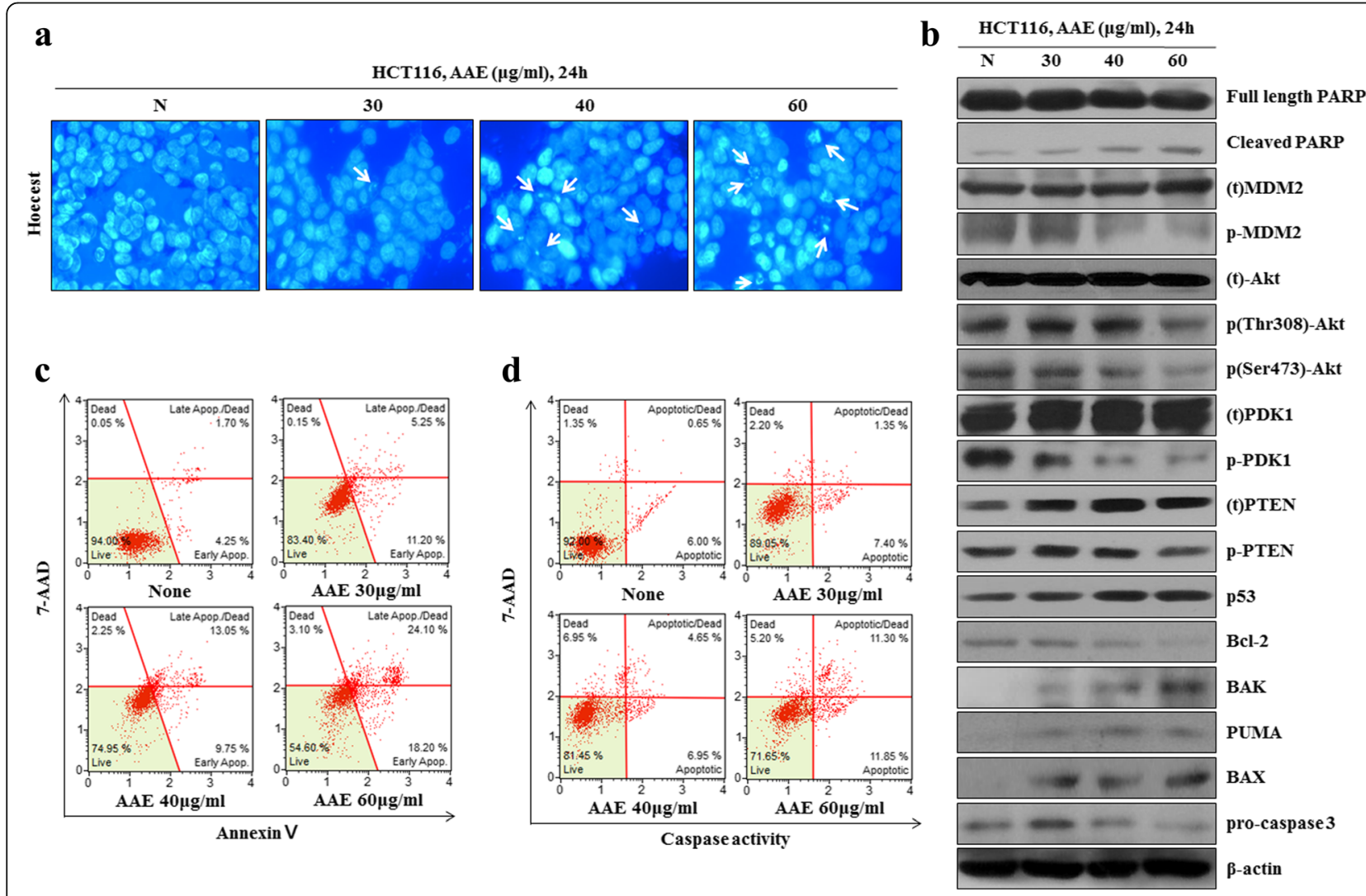

Fig. 2 AAE induces apoptosis and regulates pro-apoptotic proteins in HCT116 colon cancer cells. a Cell apoptosis observed using Hoechst 33342 staining. HCT116 were treated with AAE $(0,30,40$, and $60 \mathrm{ig} / \mathrm{ml})$ for $24 \mathrm{~h}$. Fluorescence was detected using a fluorescence microscope. Arrows indicate apoptotic bodies, which were DNA fragments produced when apoptosis occurred. $\mathbf{b}$ Apoptotic effects of different concentration AAE were evaluated by Muse ${ }^{\mathrm{TM}}$ Annexin V and Dead Cell Assay Kit. HCT116 were treated with AAE (0, 30, 40, and $\left.60 \mathrm{ig} / \mathrm{ml}\right)$ for 24 h. Data analyzed

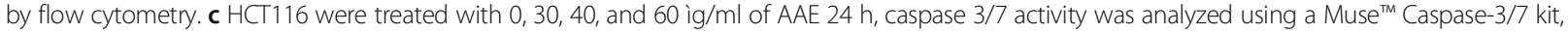
as described in Materials and Methods. $\mathbf{d}$ Cells were treated with the indicated concentrations of AAE for $24 \mathrm{~h}$. The expression of PTEN, PDK1, Akt (Thr308 and Ser473), MDM2, p53, PUMA,BCl-2, pro-caspase3 and the activation of Bax, Bak and cleaved PARP were analyzed by western blot analysis 
the Apop Tag Peroxidase In Situ Apoptosis Detection Kit (Vector Laboratories; Burlingame, CA, USA).

\section{Immunohistochemistry}

Tumor specimens from mice were fixed in 10\% formaldehyde, embedded in paraffin and sectioned into $5 \mu \mathrm{m}$ thick slices. Consecutive thin cryosections $(5 \mu \mathrm{m})$ of OCT compound (Sakura Finetek; Torrance, CA,USA) embedded tumor tissues were fixed in acetone at $4{ }^{\circ} \mathrm{C}$ for $10 \mathrm{~min}$. After washing in PBS, the sections were treated with $3 \% \mathrm{H}_{2} \mathrm{O}_{2}$ for 10 min to block endogenous peroxidase activity. The sections were then blocked with normal rabbit serum. Last, the sections were blocked and washed in PBS and incubated with specific antibodies overnight at $4{ }^{\circ} \mathrm{C}$. Negative controls were incubated with the primary normal serum IgG for the species from which the primary antibody was obtained.

\section{Statistical analysis}

Cell viability was statistically analyzed using unpaired SPSS Student's ANOVA-tests and t-tests (SPSSChicago, IL, USA). $p<0.05$ was considered statistically significant.

\section{Results}

AAE reduces cell proliferation in HCT116 colon cancer cells We investigated the cytotoxic effects of AAE through the use of a MTT Assay and LDH Release Assay on HCT116 colon cancer cells. Also, we determined the cytotoxic effects of AAE on normal human fibroblast cells. We treated cells with AAE $(20-100 \mu \mathrm{g} / \mathrm{ml})$ for 12 or $24 \mathrm{~h}$, and then assayed using a MTT Assay and LDH Assay, creating a cell morphology image used to investigate cellular viability. Figure 1a showed a decrease in cell viability. As shown in Fig. 1b, LDH release significantly increased following treatment with $20,30,40,60,80$, and $100 \mu \mathrm{g} / \mathrm{ml}$ of AAE.
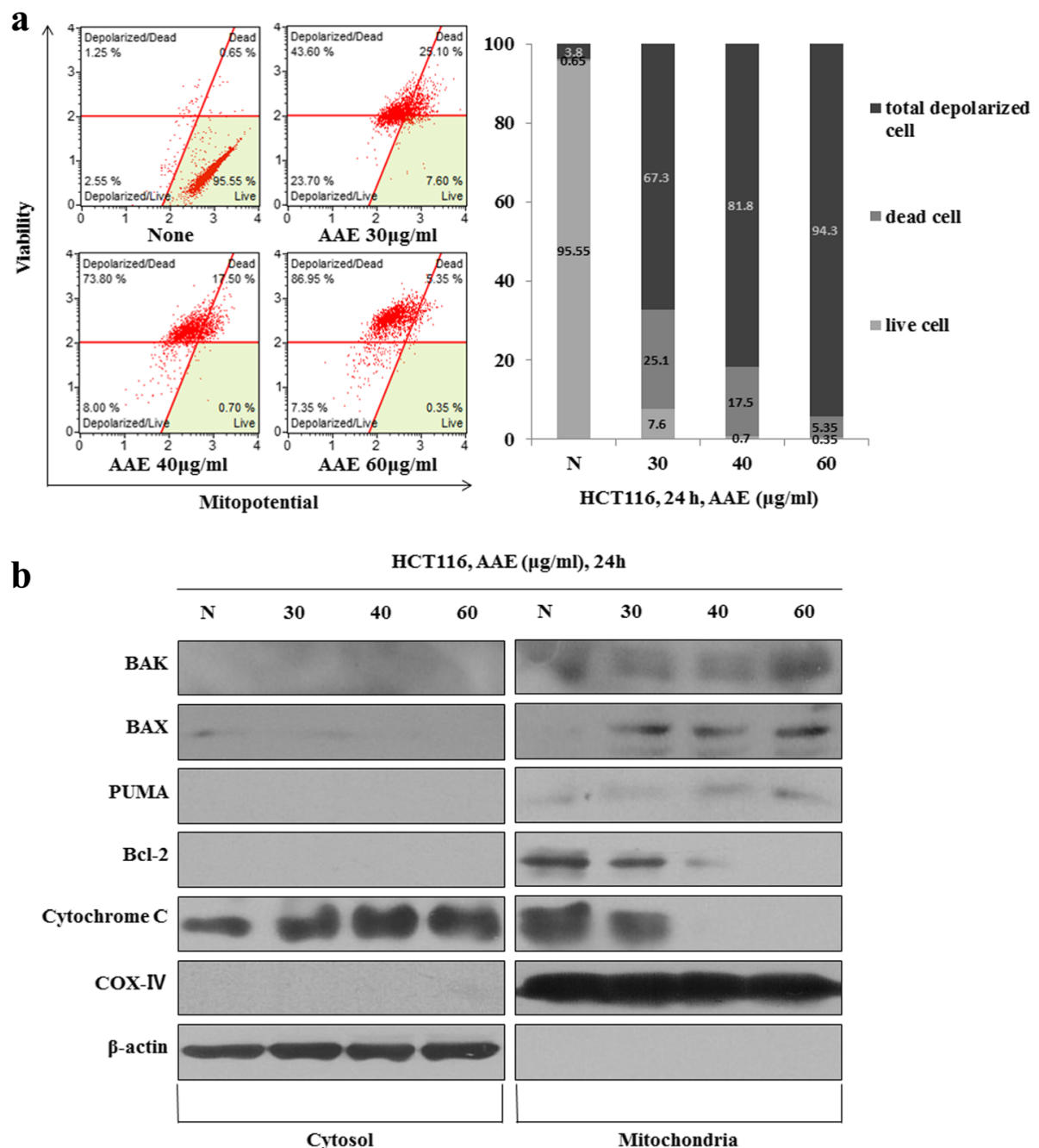

Fig. 3 AAE reduces the mitochondrial membrane potential. a Mitochondria membrane potential were evaluated by Muse ${ }^{\mathrm{TM}}$ Mitopotential kit. Cells were treated with different concentration of AAE (HCT116 were treated with 0, 30, 40, and $60 \mathrm{ig} / \mathrm{ml}$ of AAE) for $24 \mathrm{~h}$. b Fraction of mitochondria/ cytosol protein levels were analyzed by Western blotting 
However, AAE had no effect on cellular viability in normal human fibroblast cells (Fig. 1c). Compared with the control group, the group treated with AAE had induced typical apoptotic cell morphology in HCT116 cells (Fig. 1d).

\section{AAE induces apoptosis and regulates pro-apoptotic proteins in HCT116 colon cancer cells}

To determine whether AAE induction decreases cell viability involved cell death, we exerted a staining procedure using the Hoechst 33342 dye and the Muse ${ }^{\mathrm{TM}}$ Annexin V and Dead Cell Kit. Figure 2a shows that treatment with AAE $(30-60 \mu \mathrm{g} / \mathrm{ml})$ for $24 \mathrm{~h}$, leads to the apoptotic bodies increasing in a dose-dependent manner. As shown in Fig. $2 \mathrm{~b}$, the ratio of Annexin $\mathrm{V}$-positive cells was low in the control group, while the percent of Annexin V-positive cells increased in the AAE treatment groups.

In order to determine the influence of AAE on caspase-3 activation, a caspase- 3 activity assay was performed using a Muse Caspase 3/7 Activity Assay. HCT116 colon cancer cells were treated with AAE at 30, 40, and $60 \mu \mathrm{g} / \mathrm{mL}$ for $24 \mathrm{~h}$. In Fig. 2c, the levels of caspase-3 increased in a dosedependent manner in each cell line. Changes of PTEN, pPDK1, p-Akt, p-MDM2, p53, Bcl-2 and apoptosis-related proteins such as Bak, Bax, PUMA and pro-caspase-3 after treatment with AAE were determined by western blot analysis. The results showed that an increased concentration of $\mathrm{AAE}$ increased the reduction of cell survival proteins such as p-PDK1, p-Akt, p-MDM2, Bcl-2and pro-caspase-3. Moreover, the levels of PTEN, p53 and the mitochondriamediated apoptotic proteins Bak, Bax and PUMA increased in a dose-dependent manner (Fig. 2d).

\section{AAE reduces the mitochondrial membrane potential}

To investigate the mechanism of AAE-induced apoptosis, we employed a staining procedure using with the Muse MitoPotential Kit. After treatment with AAE (30-60 $\mu \mathrm{g} / \mathrm{mL})$ for $24 \mathrm{~h}$, the mitochondrial membrane potential reduced in a dose-dependent manner (Fig. 3a). In order to examine whether AAE-induced apoptotic cell death correlates with mitochondrial membrane potential, the levels of these proteins were observed in cytosol as well as mitochondria fractions. In Fig. 3b, the levels of pro-apoptotic mitochondrial proteins increased and antiapoptotic mitochondrial proteins decreased in the mitochondrial fraction.

\section{AAE regulates cytochrome $\mathrm{c}$ translocation to the cytoplasm and Bax translocation to the mitochondrial membrane}

These results showed that AAE induced cytochrome c release from the mitochondria to the cytosol and Bax

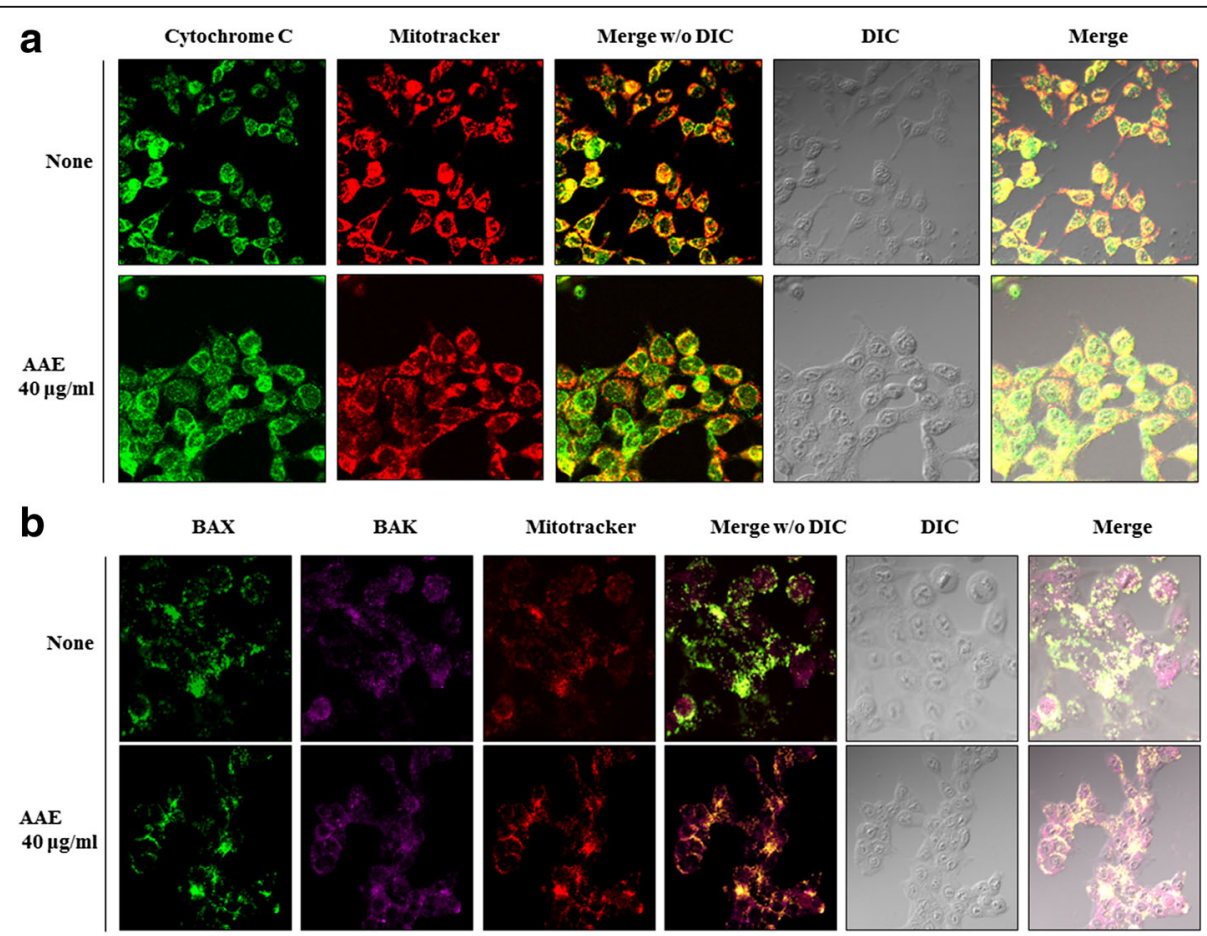

Fig. 4 AAE regulates cytochrome $c$ translocation to the cytoplasm and Bax translocation to the mitochondrial membrane. a AAE regulated cytochrome C translocation from mitochondria to cytosol. Also, (b) AAE induced BAX activation from mitochondria outer membrane to cytosol and BAX/BAK oligomerization. Cell were treated with AAE (40ig/ml) for $24 \mathrm{~h}$. Target protein and mitochondria were stained with fluorescence lag and cell locations were indicated using a DIC image 
translocation from the cytosol to the mitochondria. We treated AAE of $40 \mu \mathrm{g} / \mathrm{mL}$ for $24 \mathrm{~h}$ and stained cells in order to visualize the mitochondria, cytochrome $\mathrm{c}$, Bax and Bak (Fig. 4).

\section{AAE-induced apoptosis by p53-independent manner}

We examined the association between AAE-induced apoptosis and p53. First, we progressed a MTT assay, Annexin V and Dead cell staining, MitoPotential analysis and western blot after AAE treatment of $20 \mu \mathrm{M}$ LY294002, $20 \mu \mathrm{M}$ Nutlin, and $20 \mu \mathrm{M}$ Pifithrin- $\alpha$, along with20 $\mu \mathrm{M}$ Pifithrin- $\alpha$ prior to AAE, in HCT116 cells. Figure $5 \mathrm{a}$ showed that the group treated with Nutlin, Pifithrin- $\alpha$ only indicated similar cell viability to the control group, while treatment with AAE, LY294002 and the AAE co-treated Pifithrin- $\alpha$ group increased cell viability. As shown in Fig. 5b, the ratio of Annexin Vpositive cells was low in the control and treatment with Nutlin, Pifithrin- $\alpha$ only groups, however, the percent of
Annexin V-positive cells increased in the treatment of LY294002, AAE and AAE co-treatment Pifithrin- $\alpha$ group. To examine the mechanism by association of AAE with p53, we used a Muse MitoPotential Kit. While treatment with AAE, $20 \mu \mathrm{M}$ LY294002, $20 \mu \mathrm{M}$ Nutlin, $20 \mu \mathrm{M}$ Pifithrin- $\alpha$ and $20 \mu \mathrm{M}$ Pifithrin- $\alpha$ prior to AAE incubated for $24 \mathrm{~h}$, the mitochondrial membrane potential reduced in the LY294002, AAE and AAE co-treatment Pifithrin- $\alpha$ group however, treatment with the Nutlin and Pifithrin- $\alpha$ only groups indicated similar mitochondrial membrane potential to the control group (Fig. 5c).

Changes of PTEN, p-PDK1, p-Akt, p-MDM2 and p53 after treatment with AAE, $20 \mu \mathrm{M}$ LY294002, $20 \mu \mathrm{M}$ Nutlin, $20 \mu \mathrm{M}$ Pifithrin- $\alpha$ and $20 \mu \mathrm{M}$ Pifithrin- $\alpha$ cotreatment with AAE were determined by western blot analysis. The results showed that the levels of cell survival proteins such as p-PDK1, p-Akt, p-MDM2 decreased but levels of PTEN and p53 increased in the treatment of LY294002, AAE and AAE co-treatment

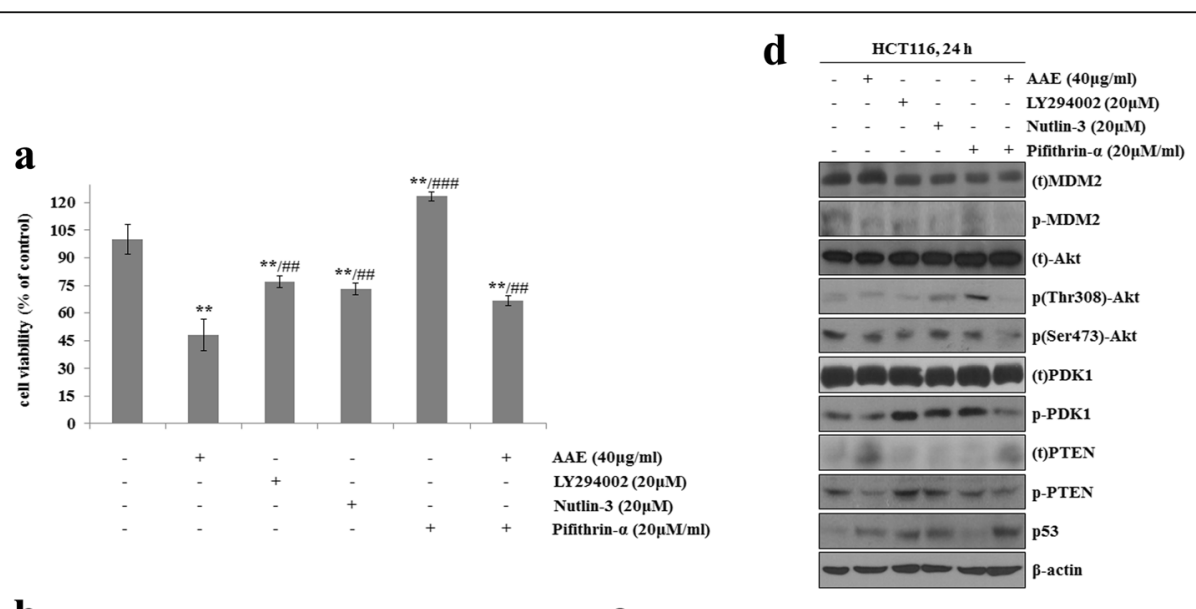

b

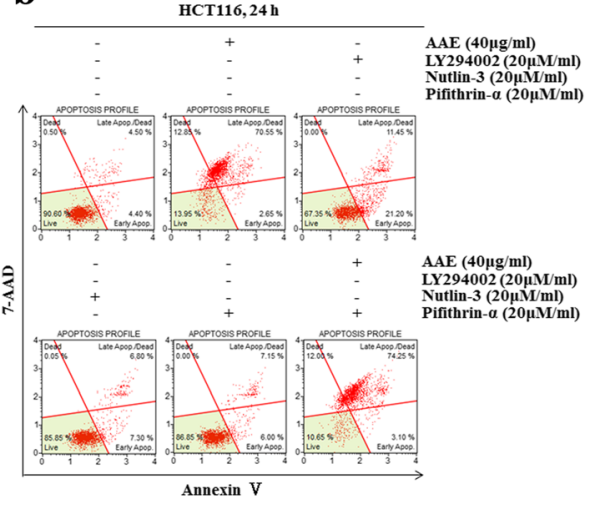

c

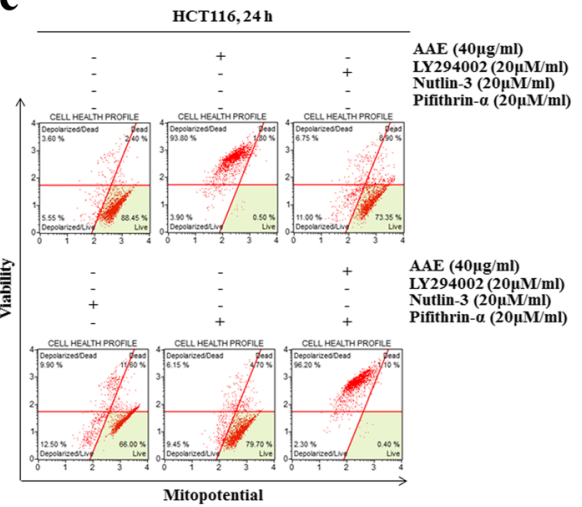

Fig. 5 AAE-induced apoptosis by p53-independent manner. Cells were treated with $20 \mu \mathrm{M}$ LY294002, $20 \mu \mathrm{M}$ Nutlin-3, $20 \mu \mathrm{M}$ Pifithrin-á and $40 \mu \mathrm{g} / \mathrm{ml}$ AAE for $24 \mathrm{~h}$. a Cells viability was measured by MTT assay (20 MM LY294002, $20 \mu \mathrm{M}$ Nutlin-3, $20 \mu \mathrm{M}$ Pifithrin-á $40 \mu \mathrm{g} / \mathrm{ml}$ AAE). The statistical analysis of the data was carried out by use of an an T-test. * $/ \# p<0.05$, ${ }^{* *} / \# \# p<0.01$ and ${ }^{* * *} / \# \# \# p<0.001$ (each experiment, $n=3$ ). b Apoptotic effects of different concentration AAE were evaluated by Muse ${ }^{\mathrm{TM}}$ Annexin V and Dead Cell Assay Kit. HCT1 16 were treated with $20 \mu \mathrm{M}$ LY294002, $20 \mu \mathrm{M}$ Nutlin-3, $20 \mu \mathrm{M}$ Pifithrin-á $40 \mu \mathrm{g} / \mathrm{ml}$ AAE for $24 \mathrm{~h}$. c Mitochondria membrane potential were evaluated by Muse ${ }^{\mathrm{TM}}$ Mitopotential kit. HCT116 were treated with

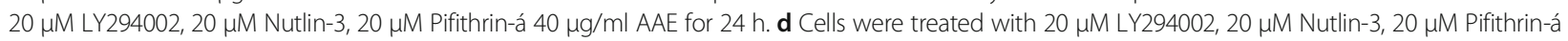
and $40 \mu \mathrm{g} / \mathrm{ml} \mathrm{AAE} \mathrm{for} 6 \mathrm{~h}$. The expression of PTEN, PDK1, Akt (Thr308 and Ser473), MDM2, p53 were analyzed by western blot analysis 
Pifithrin- $\alpha$ group. However, treatment with the Nutlin, Pifithrin- $\alpha$ only group showed similar results of cell survival proteins levels to that of PTEN and p53, the control group (Fig. 5d).

\section{AAE induces apoptosis through regulation of intracellular} signaling pathways in an HCT116 xenograft model

In order to analyze the results of AAE treatment in an HCT116 xenograft model of tumor growth, we transplanted HCT116 cells into mice and constructed a human colon cancer xenograft model. We executed histological analysis on control, delivery (DMSO mixed $\mathrm{PBS})$ and $\operatorname{AAE}(20,40 \mathrm{mg} / \mathrm{kg} /$ day) tumor tissue stained with H\&E using the TUNEL assay. The tumor volume in AAE-treated groups was less than in the control and delivery group, however, the mice weighed the same in the control group, delivery group and $\operatorname{AAE}(20,40 \mathrm{mg} / \mathrm{kg} /$ day $)$ group (Fig. 6a). The cancer tissue was degraded and the number of TUNEL positive cells increased in the AAE- treated group. Immunohistochemistry (IHC) analyses exhibited that p53 and PTEN-positive cells were increased in the AAE-treated group as compared to the control group and delivery group (Fig. 6b). Furthermore, as shown in Fig. $5 c$, apoptosis-related proteins increased in similar in vitro western blot results.

\section{AAE induces apoptosis by regulating the phosphorylation of PDK1 and Akt through the PTEN/p53-independent pathway}

To determine the direct regulating AAE proteins, we progressed a MTT assay, Annexin V and Dead cell staining, MitoPotential analysis, and western blot after being treated with AAE, $1 \mu \mathrm{M} \mathrm{BpV,} 5 \mu \mathrm{M}$ BX-795 and combination of

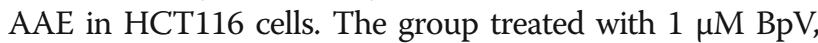
$5 \mu \mathrm{M}$ BX-795only indicated similar cell viability to the control group, while group receiving treatment $\mathrm{AAE}$ and $\mathrm{AAE}$ co-treated $1 \mu \mathrm{M}$ BpV and $5 \mu \mathrm{M}$ BX-795 saw increased the cell viability (Fig. 7a). Figure $7 \mathrm{~b}$ shows that the ratio of

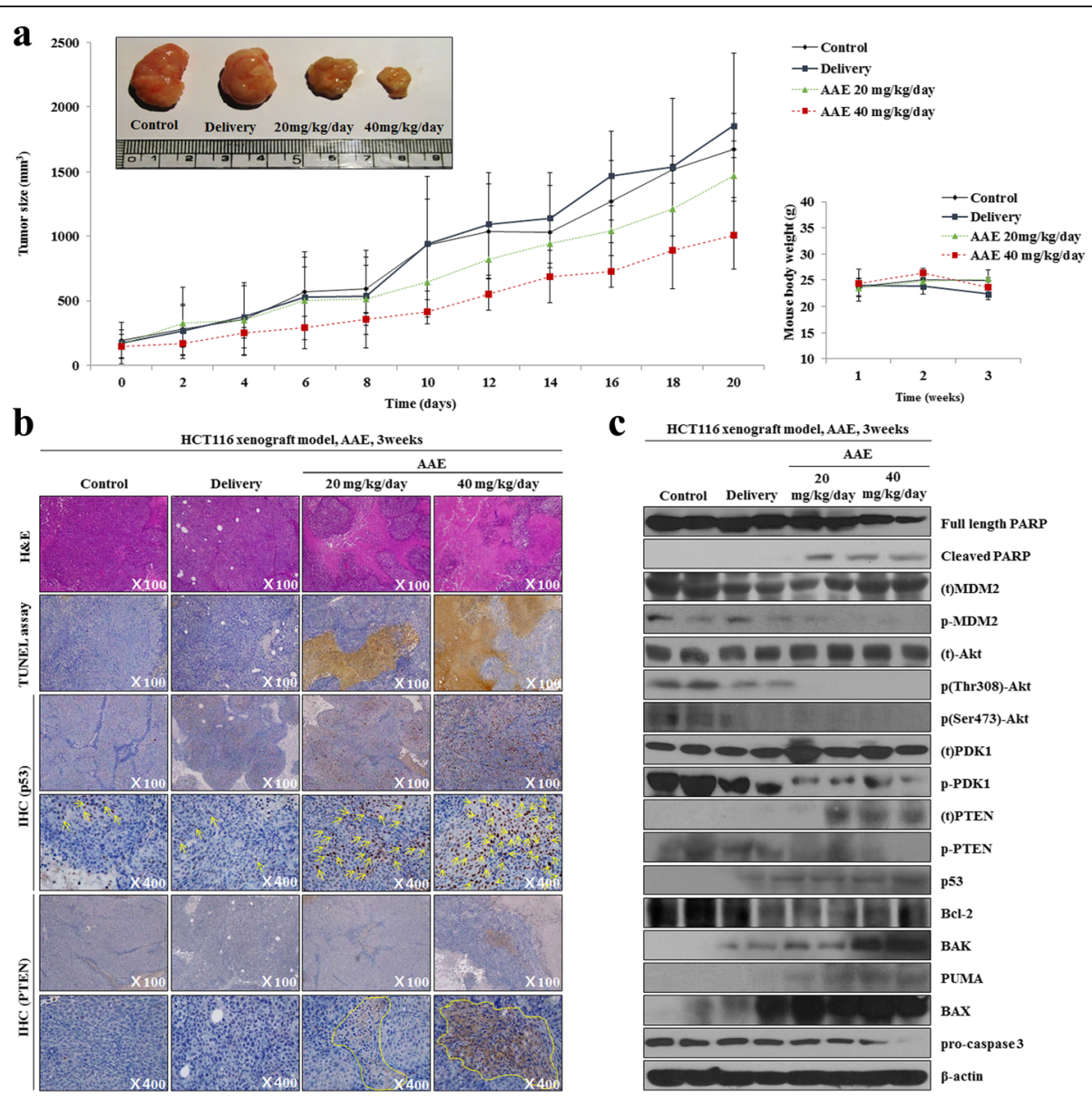

Fig. 6 AAE induced apoptosis through regulated mitochondria signaling pathways in HCT116 Xenograft model. a Tumor size and body weight of HCT116 Xenograft model mouse. AAE direct inject to tumor and tumor size were redialed each 2 day and tumor image. b Histological experiments of tumor tissue. H\&E staining, TUNEL assay and Immunohistochemical (IHC) assay were were performed at 21 day. The arrow and around indicate that specific proteins were activated by AAE treatment. c The expression of PTEN, PDK1, Akt (Thr308 and Ser473), MDM2, p53, PUMA,BCl-2, pro-caspase3 and the activation of Bax, Bak and cleaved PARP were analyzed by western blot analysis 


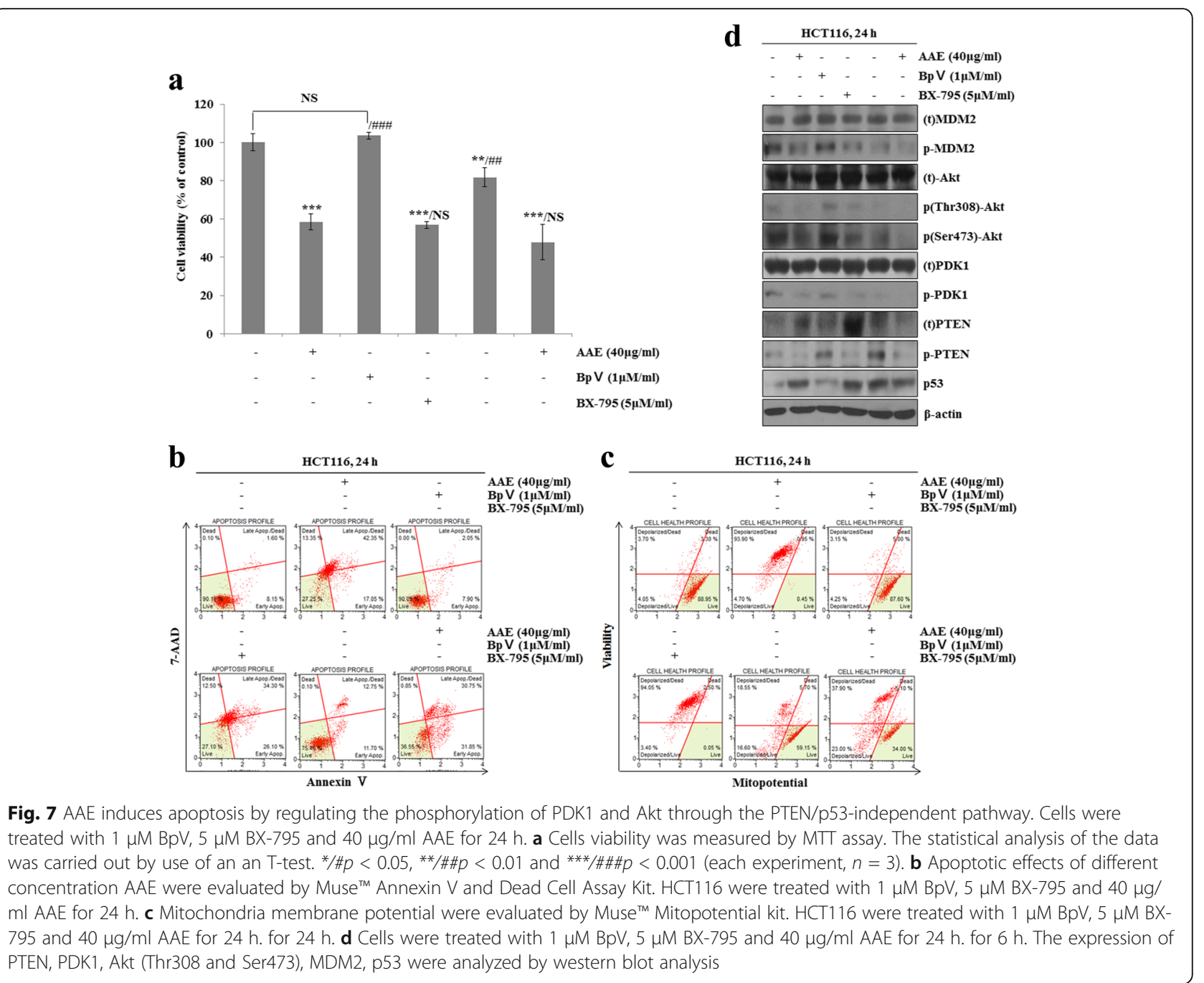

Annexin V-positive cells was low in the control and treatment with $1 \mu \mathrm{M} \mathrm{BpV}, 5 \mu \mathrm{M}$ BX-795only group. However, the ratio of Annexin $\mathrm{V}$-positive cells increased in the treatment $\mathrm{AAE}$ and $\mathrm{AAE}$ co-treated $1 \mu \mathrm{M} \mathrm{BpV}$ and $5 \mu \mathrm{M}$ BX795groups. We also used a Muse MitoPotential Kit. Mitochondrial membrane potential was reduced in the group receiving AAE, $1 \mu \mathrm{M} \mathrm{BpV}, 5 \mu \mathrm{M}$ BX-795 and a combination of AAE. However, treatment with $1 \mu \mathrm{M} \mathrm{BpV}$, $5 \mu \mathrm{M}$ BX-795only group indicated similar mitochondrial membrane potential to the control group (Fig. 7c).

The levels of PTEN, p-PDK1, p-Akt, p-MDM2 and p53 were determined by western blot analysis. Figure 7d shows that the levels of cell survival proteins such as $\mathrm{p}$ PDK1, p-Akt, p-MDM2 decreased but levels of PTEN and p53increased in the treatment of AAE, $1 \mu \mathrm{M} \mathrm{BpV}$, $5 \mu \mathrm{M}$ BX-795 and combination of AAE group. However, the treatment with $1 \mu \mathrm{M} \mathrm{BpV}, 5 \mu \mathrm{M}$ BX-795 only group showed similar levels of cell survival proteins PTEN and p53 to the control group.

\section{Discussion}

From old times, Artemisia annua Linné has been known for its anti-cancer, anti-viral and anti-bacterial properties, but the mechanisms were unknown. In this study, we investigated the effects of apoptosis and signal pathway via extract from Artemisia annua Linné in HCT116 colon cancer cells.

In this study, we focused on the effects of AAE on the induction of apoptosis. First, in order to determine the influence of AAE on cell viability, we performed a MTT assay and LDH assay after treatment with AAE. We confirmed that there is a range of cell damage contributing to significant inhibition of cell proliferation depending on the treatment.

Apoptosis at the mitochondrial level is completely dependent on Bax and Bak, as deficiency in the genes encoding these two proteins renders cells resistant to apoptosis and concomitant release of cytochrome $\mathrm{c}$ through the outer mitochondrial membrane. Cytochrome c, as a 
pro-apoptotic protein, plays an important role in triggering programmed cell death [32]. The release of cytochrome c from mitochondria directly triggers caspase- 3 activation through formation of the cytochrome c containing apoptosome complex [33]. To confirm the apoptosis mechanism, we performed a Hoechst staining, an Annexin V/Dead cell staining, caspase activity, western blot, MitoPotential staining, fraction western blot and IF staining. Taking all of the results together, AAE induced apoptotic cell death. This cell death is the AAE controlled cytochrome c released from mitochondria to cytoplasm by formation of Bax/Bak oligomeric complexes and led to translocation onto the mitochondria outer membrane. Released cytochrome c by AAE treatment was an induced caspase- 3 activity and this activity caused the apoptotic cell death.

Former studies demonstrated special compound-induced apoptosis via a p53-independent manner in HCT116 cells [34]. Thus, in order to confirm the association of AAEinduced apoptosis and p53, we treated Pifithrin- $\alpha$ (p53 inhibitor) in HCT116 cells. Our results showed an AAEinduced apoptosis via a p53-independent manner, was in cells treated with only AAE.

Our in vivo results showed AAE-induced apoptosis in a mouse xenograft model. The ratio of tumor growth was reduced in the AAE-injected group compared to the control and delivery groups. Also, the AAE-injected group revealed a growth of pro-apoptosis proteins and p53 expressed in a p53-independent manner.

When AAE-induced apoptosis occurred by p53independent pathway, we used BpV (PTEN inhibitor), and BX-795 (PDK1 inhibitor) to determine the directly regulating proteins and signal pathway by AAE. In the MTT assay, through Annexin V staining and MitoPotential staining, we confirmed that AAE-induced apoptotic cell death is mitochondria-mediated apoptotsis by PTEN independent, PDK1 dependent pathways. Through the western blot on equal terms, we detected that AAEinduced apoptosis induced activation of apoptosis related proteins by regulating the PDK1 directly.

\section{Conclusions}

In conclusion, our data reveals that AAE exerts apoptotic influences in the in vitro, in vivo situations via modulation of PDK1/Akt signaling pathways and the mitochondrial apoptosis pathway through the regulation of proteins such as Bax, Bak and cytochrome $\mathrm{c}$ in a PTEM/p53-independent manner.

\section{Abbreviations}

AAE: Extracts from Artemisia annua Linné; DMSO: Dissolved in dimethyl sulfoxide; FBS: Fetal bovine serum; IF: Immunofluorescence; IHC: Immunohistochemistry; LDH: Lactate dehydrogenase; MOMP: Mitochondrial outer membrane permeabilization; MTT: 3-(4,5-Dimethylthiazol-2-yl)-2,5-diphenyltetrazolium bromide; PDK1: Phosphoinositide-dependent protein kinase-1; PTEN: Phosphatase and tensin homolog; TUNEL: TdT-mediated dUTP nickend labeling
Funding

This paper has been supported by 2017 Hannam University Research Fund.

\section{Availability of data and materials}

The data and materials used in this study are available upon request from the authors.

\section{Authors' contributions}

EJ, BM and EK carried out the cell culture, Annexin V/Death cell assay, Mitopotential assay. EJ, GT, BM and EK carried out the experiment that is xenograft model and conceived the study. EJ wrote the paper. All authors read, designed and approved the final manuscript.

\section{Competing interests}

The authors declare that there are no competing interests.

Consent for publication

Not applicable.

Ethics approval and consent to participate

All of the animal experiments were approved by the Ethics Committee for Animal Experimentation of Hannam University (Daejeon, Korea, HNU 2016-9).

\section{Author details}

'Department of Biological Science and Biotechnology, College of Life Science and Nano Technology, Hannam University, 1646 Yuseong-daero, Yuseong-gu, Daejeon 34054, Korea. ${ }^{2}$ Department of Food Science \& Bio Technology, Shinansan University, Daehakro Danwon-gu, Ansan-city, Gyeonggi-do, Korea.

Received: 23 January 2017 Accepted: 23 March 2017

Published online: 28 April 2017

References

1. Romero MR, Serrano MA, Vallejo M, Efferth T, Alvarez M, Marin JJ. Antiviral effect of artemisinin from Artemisia annua against a model member of the Flaviviridae family, the bovine viral diarrhoea virus (BVDV). Planta Med. 2006; 72:1169-74.

2. Manulu CE, Adelakun EA, Abok Jl. Metabolites Detected in the Crude NHexane Extract of Artemisia annua Linn (Asteraceae) Cultivated in Langtang, Plateau State, Nigeria. Chem Sci Int J. 2017;18(2):1-6.

3. Räth K, Taxis K, Walz G, Gleiter CH, Li SM, Heide L. Pharmacokinetic study of artemisinin after oral intake of a traditional preparation of Artemisia annua L. (annual wormwood). AmJTrop Med Hyg. 2004;70: $128-32$

4. Towler MJ, Weathers PJ. Variations in key artemisinic and other metabolites throughout plant development in Artemisia annua L. for potential therapeutic use. Ind Crop Prod. 2015;67:185-91.

5. Weathers PJ, Arsenault PR, Covello PS, McMickle A, Teoh KH, Reed DW. Artemisinin production in Artemisia annua: studies in planta and results of a novel delivery method for treating malaria and other neglected diseases. Phytochem Rev. 2011;10:173-83.

6. Brisibe EA, Umoren UE, Brisibe F, Magalhaes PM, Ferreira JFS, Luthria D, Wu $X$, Prior RL. Nutritional characterization and antioxidant capacity of different tissues of Artemisia annua. L Food Chem. 2009;115:1240-6.

7. Ryu JH, Lee SJ, Kim MJ, Shin JH, Kang SK, Cho KM, Sung NJ. Antioxidant and anticancer activities of Artemisia annua L. and determination of functional compounds. J Korean Soc Food Sci Nutr. 2011:40:509-16.

8. Ryu JH, Kim RJ, Lee SJ, Kim IS, Lee HJ, Sung NJ. Nutritional properties and biological activities of Artemisia annua L. J Korean Soc Food Sci Nutr. 2011; 40:163-70.

9. Klayman DL. Qinghaosu (artemisinin): an antimalarial drug from China. Science. 1985;228:1049-55.

10. Avery MA, Chong WKM, Jennings-White C. Stereoselective total synthesis of (+)-artemisinin, the antimalarial constituent of Artemisia annua L. J Am Chem Soc. 1992;114:974-9.

11. Schmid G, Hofheinz W. Total synthesis of ginghaosu. J Am Chem Soc. 1983; 105:624-5.

12. Singh NP, Lai H. Selective toxicity of dihydroartemisinin and holotransferrin toward human breast cancer cells. Life Sci. 2001;70:49-56. 
13. Kang JR, Lee SJ, Hwang CR, Shin J, Kang MJ, Sung NJ. Optimization of extraction conditions for mixing beverage development of black garlic and gaeddongssuk by response surface methodology. J Agric Life Sci. 2012:46:139-49.

14. Grego-Bessa J, Bloomekatz J, Castel P, Omelchenko T, Baselga J, Anderson $\mathrm{KV}$. The tumor suppressor PTEN and the PDK1 kinase regulate formation of the columnar neural epithelium. elife. 2015; doi:10.7554/eLife.12034.

15. Tang J, Ning R, Zeng B, Li Y. Molecular evolution of PTEN Pseudogenes in mammals. PLoS One. 2016; doi:10.1371/journal.pone.0167851.

16. PTEN 3, Yin Y, Shen WH. PTEN: a new guardian of the genome. Oncogene. 2008;27:5443-53.

17. PDK1 4, Itoh Y, Higuchi M, Koji O, Kishi Y, Okazaki T, Sakai H, Miyata T, Nakajima K, Gotoh Y. PDK1-Akt pathway regulates radial neuronal migration and microtubules in the developing mouse neocortex. PNAS. 2016; doi:10.1073/pnas.1516321113.

18. Blanco-Aparicio C, Renner O, Leal JF, Carnero A. PTEN, more than the AKT pathway. Carcinogenesis. 2007;7:1379-86.

19. Vara JÁ, Casado E, de Castro J, Cejas P, Belda-Iniesta C, González-Barón M. PI3K/Akt signalling pathway and caner. Cancer Treat Rev. 2004;30:193-204.

20. Luo J, Manning BD, Cantley LC. Targeting the PI3K-Akt pathway in human cancer: rationale and promise. Cancer Cell. 2003;4:257-62.

21. Song G, Ouyang G, Bao $\mathrm{S}$. The activation of Akt/PKB signaling pathway and cell survival. J Cell Mol Med. 2005;1:59-71.

22. Altomare DA, Testa JR. Perturbations of the AKT signaling pathway in human cancer. Oncogene. 2005;24:7455-64.

23. Ogawara Y, Kishishita S, Obata T, Isazawa Y, Suzuki T, Tanaka K, Masuyama $\mathrm{N}$, Gotoh Y. Akt enhances Mdm2-mediated Ubiquitination and degradation of p53. J Biol Chem. 2002;24:21843-50.

24. Chang H, Li C, Huo K, Wang O, Lu L, Zhang Q, Wang Y, Wang W. Luteolin prevents $\mathrm{H}_{2} \mathrm{O} 2$-induced apoptosis in $\mathrm{H} 9 \mathrm{C} 2$ cells through modulating AktP53/Mdm2 signaling pathway. Biomed Res Int. 2016; http://dx.doi.org/10. 1155/2016/5125836

25. Bellamy COC. p53 and apoptosis. Bnhih Medical Bulletin. 1996;3:522-38.

26. Vaseva AV, Moll UM. The mitochondrial p53 pathway. J Cai et al/Biochimica et Biophysica Acta. 2009;1787:414-20.

27. Cai TY, Yang J, Jones DP. Mitochondrial control of apoptosis: the role of cytochrome c. J Cai et al/Biochimica et Biophysica Acta. 1998;1366:139-49.

28. Xiong SB, Mu TY, Wang GO, Jiang XJ. Mitochondria-mediated apoptosis in mammals. Protein Cell. 2014;5(10):737-49.

29. Wang CX, Youle RJ. The role of mitochondria in apoptosis. Annu Rev Genet. 2009;43:95-118.

30. Elmore SS. Apoptosis: a review of programmed cell death. Toxicol Pathol. 2007;35(4):495-516.

31. BT KILE. The role of the intrinsic apoptosis pathway in platelet life and death. J Thromb Haemost. 2009;7:214-7.

32. Zhao HM: Extrinsic and intrinsic apoptosis signal pathway review. Hongmei, licensee InTech 2012, http://dx.doi.org/10.5772/50129

33. Fulda S, Debatin KM. Extrinsic versus intrinsic apoptosis pathways in anticancer chemotherapy. Oncogene. 2006;25:4798-811.

34. Srivastava P, Yadav N, Lella R, Schneider A, Jones A, Marlowe T, Lovett G, Loughlin KO, Minderman H, Gogada R, Chandra D. Neem oil limonoids induces p53-independent apoptosis and autophagy. Carcinogenesis. 2012; 11:2199-207.

\section{Submit your next manuscript to BioMed Central and we will help you at every step:}

- We accept pre-submission inquiries

- Our selector tool helps you to find the most relevant journal

- We provide round the clock customer support

- Convenient online submission

- Thorough peer review

- Inclusion in PubMed and all major indexing services

- Maximum visibility for your research

Submit your manuscript at www.biomedcentral.com/submit
Biomed Central 